\title{
BRPKM
}

Buletin Riset Psikologi dan Kesehatan Mental

http://e-journal.unair.ac.id/index.php/BRPKM

e-ISSN: 2776-1851

ARTIKEL PENELITIAN

\section{Psychological Well Being Dewasa Awal yang Mengalami Riwayat Perceraian Orang Tua di Masa Remaja}

\author{
AULIA MAHARDIKA KIRANA \& VERONIKA SUPRAPTI* \\ Fakultas Psikologi Universitas Airlangga
}

\begin{abstract}
ABSTRAK
Perceraian orang tua di masa remaja berdampak terhadap proses perkembangannya menuju masa dewasa awal yang memberikan gambaran terkait psychological well-being. Penelitian ini menggali dan menguraikan gambaran beserta faktor tersebut menggunakan multidimensional teori dari Ryff. Penelitian ini menggunakan metode kualitatif yang melibatkan dua orang partisipan. Teknik pengumpulan data yang digunakan adalah wawancara semi terstruktur. Teknik analisis data yang digunakan adalah analisis tematik. Hasil penelitian menggambarkan kehidupan dinamis partisipan dalam mencapai kondisi psychological well being yang positif. Kedua partisipan merasakan emosi negatif saat perceraian orang tuanya yang menyebabkan mereka menghilangkan rasa sakit dengan mengejar kebahagiaan hedonic hingga akhirnya menerima, memaknai dan memaksimalkan potensinya dalam menjalani kehidupan yang mengarah ke pandangan eudaimonic. Partisipan mampu mencapai kondisi psychological well being yang positif meskipun dimensi otonomi, penguasaan lingkungan, dan tujuan hidup terlihat kurang positif pada partisipan YM. Faktor yang dapat meningkatkan psychological well being adalah dukungan sosial, evaluasi terhadap pengalaman hidup dan locus of control.
\end{abstract}

Kata kunci: dewasa awal, perceraian, psychological well-being, remaja

\begin{abstract}
Parental divorce in adolescence has an impact on the developmental process towards early adulthood which provides an overview of psychological well-being. This study explores and describes the factors using Ryff's multidimensional theory. This study uses a qualitative method involving two subjects. The data collection technique used is semi-structured interview. The data analysis technique used is thematic analysis. The results describe the dynamic life of the subject in achieving a positive psychological well-being condition. Both subjects felt negative emotions during their parents' divorce which caused them to relieve pain by pursuing hedonic happiness until finally accepting, interpreting, and maximizing their potential in living a life that leads to a eudaimonic view. Subjects were able to achieve positive psychological well-being, eventhough the autonomy, environmental mastery, and life goals were less positive for the participant (YM). Factors that can improve psychological well-being are social support, evaluation of life experiences, and locus of control.
\end{abstract}

Keywords: adolescents, divorce, early adulthood, psychological well being 
Buletin Penelitian Psikologi dan Kesehatan Mental (BRPKM), 2021, Vol. 1(1), 1003-1014

*Alamat korespondensi: Fakultas Psikologi Universitas Airlangga, Kampus B Universitas Airlangga Jalan

Airlangga 4-6 Surabaya 60286. Surel: veronika.suprapti@psikologi.unair.ac.id

Naskah ini merupakan naskah dengan akses terbuka dibawah ketentuan the Creative Common Attribution License (CC-BY-4.0) (http://creativecommons.org/licenses/by/4.0), sehingga penggunaan, distribusi, reproduksi dalam media apapun atas artikel ini tidak dibatasi, selama sumber aslinya disitir dengan baik.

\section{PENDAH UL UA N}

Perceraian sebagai sebuah cara yang harus ditempuh oleh pasangan suami-istri ketika ada masalahmasalah dalam hubungan perkawinan mereka yang tak dapat diselesaikan dengan baik (Dariyo, 2004). Secara nasional terdapat tiga wilayah yang angka perceraiannya paling tinggi menurut Pengadilan Agama, salah satunya adalah daerah Surabaya dengan jumlah kasus perceraian sebanyak 68.092 kasus (Wangge \& Hartini, 2013). Dengan putusnya suatu ikatan perkawinan tersebut (bercerai), maka akan ada dampak yang mengikutinya. Perceraian tidak hanya membawa dampak bagi orangtua saja tetapi juga pada anak (Wangge \& Hartini, 2013).

Kenakalan remaja di Banjarmasin ternyata dipengaruhi oleh perceraian orang tuanya, semua remaja yang menjadi responden dalam kasus yang diteliti merasa frustasi, bingung, sedih, kecewa, kurang mendapat kasih sayang, terlantar, dan terabaikan oleh orang tuanya pasca perceraian (Taufikurrahman, dkk., 2015). Penelitian yang dilakukan oleh Harsanti \& Gita (2013) memaparkan bahwa setelah orang tua dari partisipannya mengalami perceraian, ia mulai mengkonsumsi minum-minuman keras, memakai obat-obatan, mencopet, merusak fasilitas umum sampai melakukan hubungan seks dengan teman-teman wanitanya.

Perceraian ini menyebabkan banyak orang merasa trauma, sakit hati, kecewa, depresi dan mungkin mengalami gangguan jiwa akibat perceraian tersebut (Dariyo, 2004). Stres yang terjadi di masa kecil ini bisa berdampak jangka panjang yang mempengaruhi aspek kehidupan individu di usia dewasa. Studi mengungkapkan bahwa perceraian orang tua merupakan indikator stres yang cukup di masa kanakkanak yang pengaruhnya bertahan hingga dewasa (Huurre dkk, 2006).

Apabila dari peristiwa traumatis ini individu mempunyai evaluasi diri yang tidak baik, maka hal ini akan berpengaruh terhadap kondisi kesejahteraan psikologisnya. Hal ini sejalan dengan penelitian Ryff \& Keyes (1995) terkait beberapa faktor yang dapat mempengaruhi kesejahteraan psikologis (psychological well-being), salah satunya adalah evaluasi terhadap pengalaman hidup. Reaksi orangorang terhadap perceraian sangat bervariasi, dengan kecepatan dan tingkat penyesuaian tergantung pada berbagai sumber dan keadaan pasca-perceraian (Amato, 2012).

Untuk dapat melewati keadaan krisis dalam keluarga setelah perceraian orang tua, individu memerlukan psychological well-being yang positif, sehingga individu dapat berfungsi secara penuh dalam kehidupannya. Psychological well-being yang dikembangkan dari penelitian Ryff dan koleganya yang erat kaitannya dengan perkembangan dewasa awal. Psychological well-being dirumuskan ke dalam enam dimensi, yaitu penerimaan diri, hubungan positif dengan orang lain, otonomi, penguasaan lingkungan, tujuan hidup, dan pengembangan diri (Ryff, 1989).

Bila dalam perkembangannya dapat berjalan dengan baik, individu dewasa awal tersebut seharusnya akan memiliki tingkat psychological well being yang baik pula. Banyak individu dewasa awal yang 
mengalami efek positif setelah perceraian dan hasil tersebut tergantung pada berbagai faktor keluarga dan sosial yang membentuk pengalaman perceraian (Mohi, 2014).

Melihat beragamnya stigma dan dampak negatif yang dialami oleh remaja pasca perceraian orang tuanya, masyarakat cenderung percaya bahwa remaja dengan riwayat perceraian orang tua sudah pasti melakukan tindakan yang menyimpang atau kenakalan remaja. Padahal anak dengan latar belakang orang tua bercerai tidak selalu buruk. Hal ini dapat dipandang dari sisi positifnya. Sikap mandiri yang tercipta karena tuntutan beradaptasi dengan keadaan hidup yang harus dijalani tanpa perhatian dari orang tua dan sikap kedewasaan biasanya muncul pada diri korban keluarga broken home karena terbiasa menghadapi masalah sendiri yang membuatnya bertanggung jawab atas dirinya sendiri (Wulandri \& Fauziah, 2019).

Bahkan, remaja yang mengalami perceraian orang tuanya dapat melihat makna dan sisi positif dari peristiwa perceraian orang tuanya, mereka dalam usaha mempertanyakan dan menghayatinya terus (Mestika, 2006). Anak dari orang tua yang bercerai merasakan pengaruh positif dan kepuasan hidup (Dewi \& Utami, 2008).

Individu melalui banyak dinamika kehidupan yang membawanya mencapai kehidupan yang utuh. Namun, nyatanya untuk mencapai kondisi itu tidaklah mudah. Banyak hal dalam hidup yang harus dilalui. Untuk itu dalam penelitian ini, penulis ingin mengetahui gambaran psychological well-being dalam kaitannya dengan keadaan individu dewasa awal pasca perceraian orang tua di masa remaja, mengetahui faktor apa saja yang mempengaruhi psychological well-being, dan untuk melihat dan memahami perubahan dari kondisi psychological well-being individu di masa remaja saat awal perceraian orang tua hingga di masa kini ketika menginjak usia dewasa awal. Proses dari masa remaja menuju masa dewasa awal tentunya memberikan banyak gambaran psychological well-being maupun perubahan-perubahan psikologis yang bisa dikaji lebih dalam.

\section{Desain Penelitian}

\section{MET O D E}

Penelitian ini menggunakan tipe kualitatif dengan pendekatan intrinsic case study. Studi kasus dapat membuat peneliti memperoleh pemahaman utuh dan terintegrasi mengenai keterkaitan berbagai fakta dan dimensi dari kasus khusus yang dikaji (Poerwandri, 2009).

\section{Partisipan}

Pemilihan partisipan penelitian untuk penelitian kualitatif umumnya menitikberatkan pada jumlah yang relatif kecil dibandingkan penelitian kuantitatif. Seperti disebutkan di atas, penelitian kualitatif menekankan pada kedalaman proses dan kasus, tidak menggeneralisasi, namun berusaha mencari pemahaman yang lebih baik tentang sudut pandang dan konteks penelitian (Poerwandri, 2007). Pemilihan partisipan ini dilakukan secara purposive sampling. Peneliti menghubungi beberapa partisipan dari survei awal pertanyaan terbuka secara online dengan kriteria utama yaitu berusia 20 30 tahun dan mengalami riwayat perceraian orang tua di masa remaja.

\section{Teknik Pengumpulan Data}

Penelitian ini menggunakan teknik wawancara semi terstruktur. Wawancara ini dimulai dari isu yang dicakup dalam pedoman wawancara. Pedoman wawancara bukanlah jadwal seperti dalam penelitian kuantitatif (Rachmawati, 2007). 


\section{Analisis Data}

Pada penelitian ini, penulis menggunakan analisis data tematik. Analisis tematik merupakan cara pandang yang mampu melihat sesuatu (yang tidak dapat dilihat orang lain) dari data, terkait suatu fenomena tertentu, berdasarkan tema-tema yang muncul dari informasi umum (Boyatzis, 1998). Dalam mengembangkan tema atau kode, penelitian ini menggunakan pendekatan theory driven, dimana tema dikembangan dengan indikator atau hal-hal yang mendukung teori (Boyatzis, 1998).

\section{HAS I L P EN ELITIA N}

\section{Hasil Analisis Data Partisipan 1}

Partisipan PJR adalah seorang wanita berusia 23. Saat ini PJR merupakan mahasiswa semester akhir di Fakultas Psikologi Universitas Airlangga. PJR ialah anak kedua dari dua bersaudara. Dari kecil tinggal dengan nenek. Orang tua bercerai saat kelas 5 SD, namun baru memahami saat SMP. Ketika SMA, partisipan tinggal dengan mama \& papa tiri. Lalu, ketika kuliah memutuskan untuk kos di dekat kampus. Pandemi Covid-19 mengakibatkan partisipan tinggal di rumah mamanya. Selama tinggal disana, PJR mengaku sering cekcok dengan orang tuanya terutama papa tirinya hingga akhirnya partisipan memutuskan untuk keluar rumah dan tinggal dengan kakak sepupunya.

\section{Penerimaan diri}

Pada awal perceraian orang tuanya, partisipan tidak bisa melihat apa potensi yang harus ia gali, sehingga menyebabkan partisipan tidak memiliki kebanggaan atas dirinya dan justru merasa terpuruk karena hal itu. Partisipan menceritakan juga bahwa ia tidak memiliki waktu untuk berbagi atau bercerita dengan keluarganya terutama orang tuanya, jadi ketika ada teman, partisipan merasa sangat terbantu.

PJR memandang dirinya secara positif karena banyak orang yang mendukungnya seperti teman dan keluarga, sehingga dirinya merasa percaya diri. Partisipan tidak menjadikan kekurangan sebagai rintangan atau hal yang dapat memberhentikannya untuk hidup, karena hal itu harus diterima. Lebih lanjut, PJR juga memiliki keyakinan pada dirinya sendiri dan tidak ingin orang lain merasa kasihan padanya.

Termasuk saat partisipan memutuskan untuk meninggalkan rumah, menjadi jelas bahwa dirinya harus percaya diri bahwa ia dapat menghadapi kehidupan kedepannya. Perceraian orang tua membuatnya mengerti bahwa orang tuanya mempunyai kebahagiaannya masing-masing. Partisipan PJR menganggap jika orang tuanya dulu memutuskan untuk bertahan maka tidak akan menemukan kebahagiaan yang sama seperti sekarang, begitupun dengan dirinya.

\section{Hubungan positif dengan orang lain}

Walaupun pada awal keluar dari rumah, hubungan orang tua dengan dirinya tidak baik. Namun seiring berjalannya waktu, komunikasi yang terjalin antara PJR dan orang tuanya jauh lebih baik dari sebelumnya. Tidak ada perubahan yang signifikan pada keluarga besarnya pasca perceraian orang tua.

Dalam menjalin hubungan dengan orang lain, perceraian orang tuanya tidak mempengaruhi hal ini. Lebih lanjut, PJR menjelaskan bahwa ia tidak mengalami ketakutan dalam menjalani hubungan dengan orang di sekitarnya. Partisipan merasa bisa lebih terbuka saat ia sedang bersama teman dekatnya, ia 
bisa berbicara atau mengeluhkan banyak hal hanya kepada teman dekatnya saja. Dukungan dari luar menjadi salah satu energi positif yang bisa memotivasi partisipan di kala gundah.

\section{$\underline{\text { Otonomi }}$}

Partisipan mengatur kendali atas dirinya terhadap situasi yang dinilai dan dijalankan. PJR merasa bertanggung jawab terhadap semua hal dan berani mengambil konsekuensi. Selain itu, PJR juga yakin dengan pemikiran atau pendapatnya sendiri.

Cibiran dari keluarga yang kontra seperti menilainya sebagai anak yang tidak tahu diri, menyusahkan orang lain, hingga dinilai anak yang durhaka karena sudah meninggalkan rumah sering didapatkan. Penilaian orang tentangnya dan keluarga itu haknya, karena ia tidak merasa bahwa apa yang mereka bicarakan akan berdampak atau memberikan pengaruh pada kehidupannya.

Pasca perceraian orang tuanya, PJR pergi bermain jauh tetapi tidak izin kepada orang tua. PJR juga bermain ke rumah nenek yang jaraknya $25 \mathrm{~km}$. Selain itu, PJR juga pergi dan baru pulang larut malam yang membuatnya dimarahi. Partisipan melampiaskan emosinya dengan merokok. Saat itu partisipan merasa sudah bebas untuk berbuat apapun karena saat itu orang tuanya juga bebas dalam mengambil keputusan tanpa melibatkan partisipan.

\section{Penguasaan lingkungan}

Partisipan PJR merasa bertanggung jawab terhadap apa yang dilakukannya sekarang, termasuk bertanggung jawab terhadap orang tua dan sekitarnya. Cara partisipan menyesuaikan diri terhadap lingkungannya pasca perceraian yaitu dengan melihat hal positif yang terbentuk.

PJR bisa memanfaatkan peluang yang ada, seperti saat ada potensi di suatu bidang ia akan mengembangkannya. Selain itu, jika ia tidak menemukan kemajuan pada hal yang ia bangun, ia memilih untuk mengakhirinya dan mencari peluang lainnya.

\section{Tujuan hidup}

PJR memiliki cita-cita dan rencana dalam hidupnya. Dengan mempunyai rencana hidup, partisipan mampu merasa terarah dalam hidupnya. Beberapa tujuan hidup partisipan sudah terpenuhi.

\section{Pengembangan diri}

Partisipan menyukai tantangan yang beresiko. Lalu, dirinya menjelaskan bahwa ia suka mencoba hal baru. Saat ia mengetahui potensinya di suatu bidang, ia akan berusaha mencoba untuk menggali hal itu lebih dalam, partisipan mengembangkan potensi itu sehingga hal itu akan membawa manfaat untuknya.

PJR menyadari bahwa dirinya sudah tumbuh menjadi individu yang lebih dewasa. Ini didukung dengan beberapa sikapnya seperti selalu menghadapi segala sesuatunya dan tidak mundur.

Partisipan PJR lebih memilih bertahan. Sejalan dengan ini, partisipan merasa kehidupannya sekarang jauh lebih baik dari sebelum orang tuanya bercerai.

\section{Faktor-faktor yang mempengaruhi psychological well being}

Faktor-faktor yang mempengaruhi psychological well-being individu, yaitu evaluasi terhadap pengalaman hidup, dukungan sosial, dan locus of control. 
Dukungan terbesar partisipan berasal dari temannya karena selalu ada disaat susah dan senang. Partisipan merasa terbantu dengan teman dan orang-orang yang berada di sekitarnya. Keluarga besar dan tetangga PJR selalu mendukungnya untuk hal-hal yang bersifat positif.

PJR mengevaluasi hal yang terjadi di sekitarnya bahwa tidak semua hal berjalan sesuai dengan yang diinginkan. Berusaha boleh, tetapi jika hasilnya tidak sesuai dengan keinginan tidak menjadi masalah untuknya karena hal itu diluar kendali partisipan. Partisipan PJR memiliki evaluasi yang positif.

PJR memiliki locus of control internal karena memiliki keyakinan bahwa dirinya bertanggung jawab atas pilihan hidupnya. PJR yakin atas penentuan nasibnya sendiri.

\section{Hasil Analisis Data Partisipan 2}

Partisipan YM adalah seorang laki-laki berusia 24 tahun. Saat ini YM merupakan mahasiswa semester akhir di Fakultas Psikologi Universitas Airlangga. Anak pertama dari dua bersaudara. Mengetahui orang tuanya bercerai saat SMP kelas 2. Namun, belum memahami karena pasca perceraian tidak ada perbedaan dari saat sebelum orang tua bercerai. Tahun 2018, mama YM menjaga jarak \& memutuskan kontak dengan ayahnya. YM merasa mengalami mental breakdown. Berusaha lari dari masalah dengan menghindari lingkungannya dan mengonsumsi minuman beralkohol.

\section{Penerimaan diri}

Partisipan YM berusaha berpikir positif terhadap dirinya. YM merasa menjadi individu yang lebih ikhlas membantu orang lain, lebih lega dan lebih santai. Sifat idealis partisipan yang dulunya selalu berusaha mengusahakan segala hal tanpa memilah pun berkurang.

Partisipan merasa positif terhadap masa lalunya. Dirinya senang dengan apa yang sudah terjadi sejauh ini karena dirinya merasa selalu mendapatkan apa yang diinginkannya. Hingga saat ini, partisipan masih memiliki rasa bersalah karena belum sepenuhnya memberikan permohonan maaf dengan baik. Pada akhirnya partisipan sekarang semakin memahami bahwa perasaan bersalah itu pasti ada, akan tetapi, dirinya harus tetap melanjutkan hidup. Partisipan mengaku belajar untuk menerima dan rendah hati.

\section{Hubungan positif dengan orang lain}

Hubungan partisipan dengan kedua orang tuanya masih terjalin dengan baik. Perceraian orang tua tidak memberikan dampak pada hubungan partisipan dengan keluarga besarnya.

Perceraian orang tua pun tidak memberikan pengaruh yang berarti terhadap hubungan dengan orang lain. Justru dengan hal ini, partisipan bisa bertemu dengan orang lain yang mempunyai keadaan yang sama dengannya.

Dukungan terbanyak berasal dari temannya. Ada beberapa orang yang hadir dan mendengarkan ceritanya. Partisipan memiliki hubungan yg hangat \& saling percaya dengan orang lain.

\section{$\underline{\text { Otonomi }}$}

YM mengatakan bahwa orang lain terlibat dalam penentuan nasibnya dalam artian nasib tidak akan datang apabila orang lain tidak memintanya.

Cibiran orang lain mempengaruhi partisipan tergantung dengan konteknya. Partisipan mengevaluasi dirinya saat ada yang salah dengannya. 
Meskipun partisipan sudah mempunyai pandangan dari dirinya sendiri, dirinya berusaha mencari pandangan dari orang lain untuk melihat pendapat mana yang paling efektif. Namun apabila dalam sebuah forum diskusi mayoritas memilih pendapat yang bukan dari dirinya maka tidak masalah bagi partisipan.

Hal yang dilakukan partisipan pasca perceraian orang tuanya ialah mencari kesibukan apapun yang membuat dirinya lupa sehingga tidak terlalu memikirkan kondisinya. Partisipan mengaku mengonsumsi minuman beralkohol agar bisa terbuka di saat ada masalah yang menimpanya.

\section{Penguasaan lingkungan}

Mudah menyesuaikan diri dan tanggung jawab atas kehadiran dirinya di dalam lingkungan. Partisipan menjelaskan bahwa apapun yang sedang ia hadapi konsekuensinya akan diterima. Mampu melihat peluang, namun memilih untuk menggunakan peluang itu yg belum tentu.

Partisipan YM belum mampu mengatur prioritas dalam kehidupan sehari-harinya. Partisipan mampu beradaptasi dengan lingkungan sekitarnya namun bingung untuk mengetahui apakah lingkungannya layak untuk dirinya karena dirinya tidak pernah memilah hal ini.

\section{Tujuan hidup}

Partisipan mempunyai cita-cita dan impian, namun ada banyak pertimbangan untuk melakukan hal itu. Banyaknya pertimbangan menjadikan cita-cita dan impian partisipan tidak segera terlaksana.

Pasca perceraian, partisipan tidak memikirkan masa depannya seperti apa. Selain itu, partisipan menjelaskan bahwa lebih baik ada orang yang minta tolong untuk melakukan sesuatu daripada harus memulainya, karena jika orang memintanya melakukan sesuatu maka sudah ada tujuan yang jelas. Partisipan kesusahan dalam menentukan tujuan hidupnya sendiri.

Terkait rencana masa depan, partisipan menjelaskan bahwa ada banyak keinginan dalam hidup partisipan ke depannya, tetapi ia tidak membuat rencana yang detail untuk mewujudkan tujuan-tujuan itu.

\section{Pengembangan diri}

Partisipan YM menganggap hidup sebagai proses pembelajaran, perubahan, dan pertumbuhan yang berkelanjutan.

Partisipan menjelaskan bahwa ia merasa cukup berkembang hingga sekarang, terutama pada kegagalan yang pernah ia alami. Selain itu, partisipan YM menjelaskan bahwa ia pernah berada di posisi yang atas dan juga bawah yang menjadikannya tumbuh menjadi seseorang yang lebih paham terhadap situasi yang telah dihadapi.

Partisipan mengatakan bahwa ia lebih bijak dan dewasa terhadap apa yang terjadi di dalam hidupnya dibandingkan dirinya sebelum orang tua bercerai.

Partisipan memahami bahwa ia sadar bahwa ia memiliki potensi dalam bernyanyi, memimpin, penggagas ide, dan menjadi teman yang baik.

Partisipan menjelaskan bahwa sampai sekarang ia suka mencoba hal baru.

\section{Faktor-faktor yang mempengaruhi psychological well-being}

Faktor-faktor yang mempengaruhi psychological well-being individu yang mengalami riwayat perceraian orang tua di masa remaja adalah evaluasi terhadap pengalaman hidup dan dukungan sosial. 
Partisipan memiliki evaluasi yang positif. Di masa lalu, partisipan sempat melakukan hal yang ia sesali sehingga dirinya dipenuhi rasa bersalah. Perceraian orang tua memiliki banyak hal yang dapat dipelajari. Partisipan sempat merasakan kegagalan yang membuatnya dipenuhi rasa sakit dan kecewa. Partisipan telah introspeksi dan belajar memaafkan dirinya. Partisipan mengambil semua hal yang terjadi dalam hidupnya sebagai sebuah proses pembelajaran untuk bertingkah laku di kehidupannya di masa depan. Proses pendewasaan selama hidup, membuatnya tidak menutup diri untuk terus belajar lagi.

Dukungan sosial juga menjadi faktor penting dalam psychological well-being. Partisipan mempunyai teman-teman yang mengerti dan memahami kondisi partisipan. Teman-temannya selalu mendukung YM. Partisipan YM merasa berterima kasih kepada dirinya sendiri dan orang-orang di sekitarnya yang selalu memberikan dukungan tiada henti.

\section{I S K U S I}

Individu dewasa awal yang mengalami riwayat perceraian orang tua di masa remaja mengalami perubahan psikologis karena perceraian orang tuanya. Perubahan tersebut memiliki kesamaan di antara kedua partisipan, yaitu merasa marah dan kecewa. Hal ini hanya dialami oleh partisipan pada awal mereka menyadari arti dan makna dari perceraian orang tua. Masing-masing partisipan memerlukan waktu yang berbeda untuk menyesuaikan diri dan menerima kondisi perceraian orang tuanya. Partisipan memiliki pengalaman yang berbeda dalam menjalani masa kritis pasca perceraian orang tuanya. Pengalaman yang berbeda ini dilihat dari kondisi partisipan sesaat setelah mereka menyadari bahwa orang tuanya telah berpisah dan kemampuan partisipan untuk menyesuaikan diri atas kondisi tersebut.

Meskipun cara merespon perceraian orang tua kedua partisipan berbeda, namun mereka sama-sama mengejar kenikmatan dan menghindari rasa sakit yang mengarah ke pandangan hedonik. Hedonic wellbeing memiliki tujuan hidup untuk mengalami kenikmatan maksimal dan kebahagiaan untuk menghindari rasa sakit (Ryan \& Deci, 2001). Well-being dalam pandangan hedonik cenderung mencari kebahagiaan dengan menghindari perasaan sakit atau hal-hal yang tidak menyenangkan (Vanhoutte, 2014).

Kedua partisipan berusaha menghindari rasa sakit dengan mencari kebahagiaan sementara yaitu melakukan perilaku negatif seperti merokok dan mengonsumsi minuman beralkohol. Kenikmatan yang dikejar ini akan menimbulkan well-being yang bersifat sementara dan berkembang menjadi sebuah kebiasaan yang akan menghilangkan esensi sebagai suatu hal bermakna (Ryff, 1989).

Setelah berfokus untuk menghilangkan rasa sakit yang mereka punya, kedua partisipan menyadari harus berfungsi secara penuh dan mencapai kesejahteraan secara utuh. Keduanya berusaha menjalani hidup dengan menggunakan potensi yang ada dalam diri mereka. Hal ini sejalan dengan perspektif eudaimonic. Perspektif eudaimonic bahwa individu-individu yang mengoptimalkan potensinya dan mengaktualisasikan dirinya dengan merefleksikan nilai-nilai yang dimiliki sepenuhnya dapat membuat individu mencapai kondisi bahagia (Ryan \& Deci, 2001). Pandangan eudaimonic inisering dipakai oleh konsep psychological well-being.

Psychological well being merujuk pada perasaan yang tidak hanya merasa terbebas dari stress ataupun gangguan mental, namun tentang memiliki harga diri yang positif, penguasaan dan otonomi diri, memiliki relasi, memiliki tujuan hidup dan makna hidup, dan memiliki keinginan untuk terus 
berkembang Ryff \& Keyes (1995). Psychological well being adalah suatu kondisi dimana individu mempunyai pandangan positif terhadap dirinya sendiri, sehingga seseorang mampu mencapai kehidupan yang lebih baik (sejahtera) dengan tidak menjadikan masa lalu sebagai beban dalam hidupnya (Ryff, 1989).

Kedua partisipan menunjukkan hasil yang dinamis dalam mencapai kondisi kesejahteraan psikologis. Dinamika ataupun perubahan psychological well being pada individu dewasa awal bisa dilihat ketika keduanya menunjukkan perubahan yang cukup signifikan dalam hidupnya. Hal ini bisa dilihat ketika PJR dan YM menunjukkan banyaknya perubahan yang terjadi dalam hidupnya, baik dalam penerimaan diri maupun dalam pengembangan dirinya. Perubahan ini meliputi perubahan psikologis dan juga perubahan finansial.

PJR merasa lebih kuat, lebih tangguh serta mampu menghidupi dirinya sendiri. YM berusaha menjadi pribadi yang lebih baik untuk dirinya sendiri dan orang lain. Kemampuan untuk mengatasi dan beradaptasi ketika menghadapi kejadian yang berat batau masalah yang terjadi dalam kehidupan disebut resiliensi (Hadianti dkk, 2017).

Hurlock (2003) menjelaskan bahwa penerimaan diri adalah suatu kemampuan dan keinginan dari individu untuk hidup dengan karakteristik yang ada pada dirinya. Pada aspek penerimaan diri, kedua partisipan menerima kelebihan dan kekurangan yang ada pada dirinya. PJR tidak menganggap kekurangan sebagai alasan untuk tidak bisa maju ke depannya. Kedua partisipan mengaku dapat mengambil pelajaran dari situasi keluarganya seiring bertambahnya usia. Kedua partisipan mampu memiliki pandangan positif mengenai permasalahan yang dialaminya. Penerimaan bukan berarti menoleransi perilaku buruk, tetapi untuk mengakui keadaan yang tidak baik-baik saja (Germer, 2009).

Bagi Germer (2009) penerimaan merujuk pada pilihan untuk mengalami sensasi, perasaan, menerima perasaan atau pikiran. Penerimaan diri sendiri saat mengalami suatu keadaan yang menyakitkan disebut self-compassion (Germer, 2009). Kedua partisipan juga dapat melibatkan pemahaman agamanya sehingga dapat menerima keadaan yang terjadi pada keluarganya. PJR yakin semua hal yang terjadi merupakan rencana Allah. YM memaknai bahwa semua yang diinginkan belum tentu baik untuknya, perlu Tuhan untuk memberikan arahan. Religiusitas berpengaruh atas penerimaan diri individu (Badaria \& Astuti, 2004).

Pada aspek hubungan positif dengan orang lain, perceraian orang tua PJR dan YM tidak memberikan dampak pada hubungan keluarganya. Kedua partisipan mempunyai hubungan yang positif dengan keluarga besarnya. Pada partisipan PJR, setelah ia memutuskan untuk keluar dari rumah, komunikasi yang terjalin dengan orang tuanya justru lebih positif, Kedua partisipan lebih bisa dekat dan terbuka dengan temannya. Keduanya, lebih bisa menceritakan dan berkeluh kesah pada teman-temannya. Selain itu, mereka juga sama-sama tidak ingin memperlihatkan kesulitannnya pada keluarganya.

Kedua partisipan menerima dukungan dari berbagai pihak. Dukungan sosial diartikan sebagai kenyamanan, kepedulian, penghargaan atau bantuan yang diterima individu dari individu lain atau kelompok (Uchino dalam Sarafino \& Timothy, 2011). Dukungan dari luar menjadi salah satu energi positif yang bisa memotivasi kedua partisipan untuk melangkah ke depannya. Rasa kesepian yang dialami oleh partisipan pasca perceraian orang tua juga telah tergantikan dengam dukungan sosial yang didapat oleh partisipan dari orang di sekitarnya. Sarason, dkk. (1990) menjelaskan bahwa dukungan sosial dapat berperan penting untuk mengatasi kesepian yang dialami oleh individu.

Individu memiliki otonomi baik jika mereka mampu mandiri dan mengarahkan dirinya sendiri, mampu menghadapi tekanan sosial, dapat mengatur tingkah laku dari dalam diri dan mengevaluasi diri dengan 
standar pribadi (Ryff, 1989). Pada aspek otonomi, kedua partisipan menunjukkan hasil yang berbeda. Partisipan PJR yakin dengan pemikiran dan pendapatnya sendiri. Apabila dirinya membutuhkan diskusi, PJR hanya berdiskusi dengan orang terdekat dan itu pun hanya sebagai bahan pertimbangan. Bukan menjadi sebuah keputusan untuk dirinya. Lain hal dengan partisipan YM, dirinya cenderung mengikuti keputusan orang lain. Orang lain sangat berpengaruh pada pengambilan keputusan partisipan YM.

Individu yang memiliki penguasaan lingkungan yang baik adalah individu yang mampu menguasai dan mengatur lingkungan, mengontrol berbagai kegiatan eksternal yang kompleks dengan menggunakan kesempatan yang ada secara efektif, serta mampu memilih atau menciptakan konteks yang sesuai dengan kebutuhan-kebutuhan dan nilai-nilai yang dianut (Ryff, 1989). Pada aspek penguasaan lingkungan, PJR mampu memanfaatkan peluang yang ada. Sedangkan pada partisipan YM, belum mampu mengambil tindakan untuk peluang di sekitarnya. Kedua partisipan terbiasa dalam hal adaptasi atau penyesuaian diri. Namun, partisipan YM kurang mampu memprioritaskan dan meremehkan tanggung jawab partisipan. Partisipan kurang mampu memilih teman yang membawa dampak positif dan menghindari teman-teman yang berdampak negatif.

Individu dianggap baik dalam dimensi tujuan hidup apabila individu tersebut memiliki kepercayaan yang dapat memberinya arti dan tujuan hidup, memiliki pemahaman yang jelas akan tujuan dan arah hidup yang dijalani, memiliki arah dalam hidupnya dan merasakan makna kehidupannya saat ini maupun masa lalunya (Ryff, 1989). Partisipan PJR menunjukkan hasil yang lebih positif dibanding YM. PJR dan YM mempunya cita-cita dalam hidupnya. PJR mempunyai rencana dalam hidup namun tidak dengan YM. YM menunggu orang lain untuk melakukan sesuatu daripada harus memulainya.

Pada aspek pengembangan diri, kedua partisipan memiliki kesamaan senang mencoba hal baru terutama di bidang usaha. Kedua partisipan juga menjadi lebih dewasa dibanding saat awal perceraian. Kedua partisipan juga dapat mengembangkan potensinya. Keduanya juga merasa kehidupannya jauh lebih baik dan tidak ada penyesalan terhadap apa yang sudah terjadi.

Menurut Ryff \& Keyes (1995) mengungkapkan beberapa faktor yang dapat mempengaruhi kesejahteraan psikologis (psychological well-being) seseorang, antara lain faktor demografis, dukungan sosial, evaluasi terhadap pengalaman hidup, dan locus of control. Dalam penelitian ini kondisi psychological well-being partisipan dipengaruhi oleh faktor dukungan sosial, evaluasi terhadap pengalaman hidup dan locus of control. Dukungan eksternal sangat menunjang psychological well-being individu dengan riwayat perceraian.

Kedua partisipan telah berhasil melalu masa kritis pasca perceraian orang tuanya. Proses yang begitu panjang dijalani keduanya dengan penuh perjuangan. Menurut Fitri dan Kusumaningtyas (2019) kebahagiaan tidak selalu diartikan dengan terpenuhinya segala kebutuhan individu. Dari hasil penelitian, kedua partisipan merasa cukup bahagia dengan apa yang telah dijalaninya hingga saat ini.

\section{S I M P U L A N}

Berdasarkan pemaparan yang telah diuaraikan di atas dapat ditarik simpulan dari penelitian ini yaitu individu dewasa awal yang mengalami perceraian orang tua di masa remaja yang menjadi partisipan penelitian menunjukkan hasil yang beragam dan memiliki keunikan di setiap dimensi psychological well-being. Kedua partisipan mampu melewati masa kritis pasca perceraian orang tuanya dan mampu mencapai kondisi psychological well-being yang positif. Meskipun pada partisipan YM beberapa dimensi yaitu otonomi, penguasaan lingkungan dan tujuan hidup terlihat kurang positif. Kondisi psychological 
well being partisipan juga dipengaruhi oleh factor dukungan social, evaluasi terhadap pengalaman hidup dan locus of control.

\section{U C A P A N TERIMAKASIH}

Terima kasih penulis ucapkan kepada Allah SWT, keluarga, sahabat dan rekan-rekan serta kepada semua pihak yang sudah terlibat dalam memberi dukungan dan membantu dalam proses penelitian ini hingga selesai.

\section{DEKLARASI POTENSI TERJADINYA KONFLIK KEPENTINGAN}

Aulia Mahardika Kirana dan Veronika Suprapti tidak bekerja, menjadi konsultan, memiliki saham, atau menerima dana dari perusahaan atau organisasi maupun yang mungkin akan mengambil untung dari diterbitkannya naskah ini.

\section{PUSTAKA ACUAN}

Amato, P. R. (2012). The Consequences of Divorce for Adults and Children: An Update. 5-24.

Badaria, H., \& Astuti, Y. D. (2004). Religiusitas dan Penerimaan Diri pada Penderita Diabetes Melitus. Vol 9, No 17 .

Boyatzis, R. (1998). Transforming Qualitative Information: Thematic Analysis and Code Development. Thousand Oaks: Sage Publications, Inc.

Dariyo, A. (2004). Memahami Psikologi Perceraian Dalam Kehidupan Keluarga , 94.

Dewi, P. S., \& Utami, M. S. (2008). Subjective Well Being Anak dari Orangtua yang Bercerai. Jurnal Psikologi Vol 35 No 2.

Fitri, Susi \& Kusumaningtyas, Annisa. (2019). Pengembangan buku bantuan diri untuk membantu remaja memelihara ikatan kelekatan (attachment bond) yang orangtuanya bercerai SMA se-DKI Jakarta. INSIGHT: Jurnal Bimbingan Konseling. Vol.8 (1), 78-91.

Germer, C. K. (2009). The Mindful Path to Self-Compassion: Freeing Yourself from Destructive Thoughts and Emotions. New York: Guilford Press.

Hadianti, S. W., Nurwati, N., \& Darwis, R. S. (2017). Resiliensi remaja berprestasi dengan latar belakang orang tua bercerai. Vol 4 No 2.

Hurlock, E. B. (2003). Psikologi Perkembangan: Suatu Pendekatan Sepanjang Rentang Kehidupan. Jakarta: Erlangga

Mestika, D. (2006). Gambaran proses memaafkan pada remaja yang ortang tuanya bercerai. Jurnal Psikologi Vol. 4 No. 1, 1-13.

Mohi, G. (2014). Positive Outcomes of Divorce: A Multi-Method Study on the. HIM 1990-2015, 1-41.

Poerwandri, E. K. (2007). Pendekatan Kualitatif dalam penelitian Psikologi. Jakarta: LPSP3 Universitas Indonesia. 
Poerwandri, E. K. (2009). Pendekatan Kualitatif. Cetakan ketiga. Depok: Lembaga Pengembangan Sarana Pengukuran dan Pendidikan Psikologi Fakultas Psikologi UI.

Rachmawati, I. N. (2007). Pengumpulan Data Dalam Penelitian Kualitatif: Wawancara. Jurnal Keperawatan Indonesia Vol 11 No 1.

Ryan, R. M., \& Deci, E. L. (2001). On Happiness and Human Potentials: A Review of Research on Hedonic and Eudaimonic Well-Being. Annual Review of Psychology 52(1), 141-166.

Ryff, C. D. (1989). Happiness Is Everything, or Is It? Explorations on the Meaning of Psychological WellBeing. Journal of Personality and Social Psychology, 1069-1081.

Ryff, C. D., \& Keyes, C. L. M. (1995). The Structure of Psychological Well-Beng Revisited. Journal of Personality and Social Psychology.

Sarafino, E. P., \& Timothy, W. S. (2011). Health Psychology: Biopsychosocial Interactions, 7th edition. Amerika Serikat: John Wiley \& Sons, Inc.

Sarason, I. G., Pierce, G. R., \& Sarason, B. R. (1990). Social Support and Interactional Processes: A Triadic Hypothesis. Journal of Social and Personal Relationships.

Vanhoutte, B. (2014). The Multidimensional Structure of Subjective Well-Being In Later Life. Journal of Population Ageing 7(1), 1-20.

Wangge, B. D., \& Hartini, N. (2013). Hubungan antara Penerimaan Diri dengan Harga Diri pada Remaja pasca Perceraian Orangtua. Jurnal Psikologi Kepribadian dan Sosial Vol. 2 No.1, 1-6.

Wulandri, D., \& Fauziah, N. (2019). Pengalaman Remaja Korban Broken Home (Studi Kualitatif Fenomenologis). Jurnal Empati, Volume 8, Nomor 1, 1-9. 